\title{
nature
}

19 February 2004 Volume 427 Issue no 6976

\section{Leapfrogging the power grid}

The desire to mitigate climate change, and opportunities to empower consumers in the developed and developing worlds, all point towards a need for less-centralized energy generation. It's time to further boost hydrogen research.

Y ou purr your pollution-free hydrogen car into your garage, plug it into the wall, and ponder your electricity meter spinning anticlockwise. The car's fuel cell not only powers your house but, through an intelligent chip, auctions off the surplus electricity to local power brokers. Sooner than you may think, your lab or university might be sending out electricity bills instead of paying them. Technologies, green imperatives and liberalized energy markets are converging to reinvent the century-old electricity grid.

Alongside power plants, oil barons and high-voltage pylons, local generators will cheaply and cleanly pump out power from villages, faculties and backyards, and electricity consumers will also become vendors. Underpinning this shift, computer scientists are creating an intelligent, responsive 'energy web', where local supply and demand would be micromanaged in an electronic energy marketplace.

World energy needs will double by 2050 and we urgently need sources that don't produce carbon dioxide or other pollutants. Decentralized generation puts technological choices in consumers' hands. The technology is available to bring small, local energy sources, or 'micropower', better into the electricity equation, from gas turbines, hydro and wind power and sugar-cane biomass to nanoscale solar cells embedded in the bricks and slates of houses.

For countries like the United States that already have grids, decentralized generation will ease gridlock, radically improve energy efficiency, cut carbon emissions and provide better resilience to failures and terrorist attacks on vulnerable networks.

But for the 2 billion people without electricity, micropower could let them leapfrog the grid. Just as countries that had never seen an expensive copper telephone network jumped straight to mobile phones, so decentralized generation technologies offer the chance for them to leapfrog the grid and prosper. That was the take-home message from a meeting of energy companies, researchers and policy makers in Paris last week (www.wtn.net/new/registration/ 2004/energy/index.jsp).

\section{Clean and green}

The meeting concluded that an array of micropower technologies, from small gas turbines to solar panels, have matured sufficiently to provide electricity to developing countries, even in remote rural areas. Demand for electricity in poor countries is set to rocket. Minimizing the resulting surge in carbon emissions requires them to explore micropower to help them meet demand in cleaner ways and broaden their energy sources to become less dependent on oil.

Progress in industrialized countries will be key not just to convincing poorer countries that this is the way forward, but also to reducing the cost, by first creating a market in the developed world. Distributed generation is already happening, but its share of total electricity production worldwide has remained flat at $7 \%$ over the past three years, according to the World Alliance for Decentralized Energy (www.localpower.org). In countries with proactive energy policies, such as Denmark, this share is about $50 \%$.

Efficient gas turbines at the point of use are the most immediately promising form of decentralized generation. Although they largely burn fossil fuels such as natural gas, they are already cleaner and more efficient than grid electricity. Excluding large hydroelectric facilities, renewables account for only a few percent of total world production, but Denmark and Luxembourg obtain around $17 \%$ of their electricity from them. The technological potential is there to expand renewables. Wind is the fastest-growing energy source, accounting for $2 \%$ of European needs. The costs of solar energy have plummeted by $90 \%$ since the 1970 s, bringing it, at around $\$ 4.50$ per watt, tantalisingly close to the $\$ 3$ per watt of grid electricity — and that's not taking into account the environmental costs and hidden subsidies of the grid.

The ultimate micropower source is the fuel cell, which converts hydrogen to electricity without combustion or moving parts. It overcomes the main drawback of renewable energy sources, that electricity is lost if not immediately used. Excess electricity can be converted to hydrogen and stored to make electricity again. The most immediate cost-effective source of hydrogen is cracking it from natural gas. This would not reduce carbon emissions or the West's dependence on imports, but could provide a stepping stone to the hydrogen economy.

\section{More hydrogen, please}

Advocates of hydrogen argue that it has been too glibly dismissed as an energy carrier (see, for example, www.rmi.org/images/other/ E-20HydrogenMyths.pdf). A report released earlier this month by the US National Academies - The Hydrogen Economy: Opportunities, Costs, Barriers, and Red Needs - argues that a wholesale shift to a hydrogen economy is still decades away and that major cost obstacles must be overcome, but nevertheless signals a route towards a transition (see www.nap.edu/books/0309091632/html).

As the academy report emphasizes, incremental changes are not enough — making the hydrogen economy a reality will require "a comprehensive, long-range program of innovative, high-risk/ high-payoff basic research" in catalysis, nanomaterials, membranes and separation. The report recommends expanding US research to include distributed hydrogen production systems, hydrogen storage and solar energy for hydrogen production.

Distributed generation could go some way to solving the automobile industry's Catch 22 of creating a hydrogen infrastructure: why develop hydrogen cars when there is no distribution network, and why develop a distribution network if there are no hydrogen cars? Fuel cells for generating electricity need to become a common feature of factories, hospitals, fork-lift trucks in Walmart's nearly 6,000 outlets, and fleet vehicles such as city buses, government vehicles and delivery trucks. Pilot initiatives have already been established.

A level playing field is key to more research. Many US states and countries are passing laws that allow customers to sell their electricity, which in the past would have landed you in jail. California's decree that by next year a tenth of all cars sold in the state must not produce emissions is waking up US car-makers. And EU laws require member states to have $12 \%$ of all energy renewable by 2010 . As fuel cells and other sources of micropower gain market share, market forces will drive down costs and provide research incentives.

Hydrogen as a widely used energy carrier is essential and inevitable. Scientists, technologists, governments and philanthropists should do much more to hasten its arrival. 